\title{
Differences in therapeutic approach to juvenile dermatomyositis between Europe and Latin America
}

L Trail*1, C Ferrari1 $^{1}$, R Cuttica ${ }^{2}$, MM Katsicas ${ }^{3}$, R Russo ${ }^{3}, \mathrm{M}$ Bandeira ${ }^{4}$, V Ferriani ${ }^{5}$, S Oliveira ${ }^{6}$, C Saad-Magalhaes ${ }^{7}$, CA Silva ${ }^{8}$, V Baca9, R BurgosVargas $^{10}$, E Solis-Vallejo ${ }^{11}$, S Maillard ${ }^{12}$, C Pilkington ${ }^{12}$, R Barcellona1,

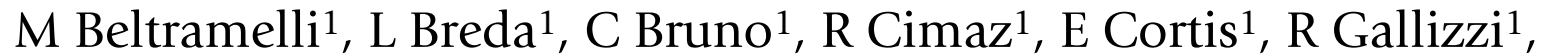
F Garofalo${ }^{1}$, A Meini ${ }^{1}$, R Podda ${ }^{1}$, A Stabile ${ }^{1}$, A Martini ${ }^{1}$ and A Ravelli ${ }^{1}$

Address: ${ }^{1}$ Italian Pediatric Rheumatology Study Group, Italy, Italy, ${ }^{2}$ Hospital General de Ninos Pedro de Elizalde, Buenos Aires, Argentina, ${ }^{3}$ Hospital Garrahan, Buenos Aires, Argentina, ${ }^{4}$ Hospital Pequeno Principe, Curitiba, Brazil, ${ }^{5}$ Hospital da Universidade, Ribeirao Preto, Brazil, ${ }^{6}$ Universidade Federal do Rio de Janeiro, Rio de Janeiro, Brazil, ${ }^{7}$ Hospital das Clínicas UNESP, Botucatu, Brazil, ${ }^{8}$ Hospital Das Clinicas, Sao Paulo, Brazil, ${ }^{9} \mathrm{CMN}$ Siglo XXI, Mexico City, Mexico, ${ }^{10}$ Hospital General de México, Mexico City, Mexico, ${ }^{11} \mathrm{CMN}$ La Raza, Mexico City, Mexico and ${ }^{12} \mathrm{Great}$ Ormond Street Hospital, London, UK

* Corresponding author

from I5th Paediatric Rheumatology European Society (PreS) Congress

London, UK. 14-17 September 2008

Published: 15 September 2008

Pediatric Rheumatology 2008, 6(SuppI I):P2 I $\quad$ doi:10.II86/I546-0096-6-SI-P2I4

This abstract is available from: http://www.ped-rheum.com/content/6/SI/P2I4

(c) 2008 Trail et al; licensee BioMed Central Ltd.

\section{Objective}

To investigate the differences in the therapeutic approach to juvenile dermatomyositis (JDM) between pediatric rheumatology centers in Europe (EU) and Latin America (LA).

\section{Methods}

490 patients with JDM and disease duration $>2$ years seen in 27 centers in EU (Italy, UK) and LA (Argentina, Brazil, Mexico) after 1980 were enrolled in a multinational, multicenter study aimed to investigate the long-term disease outcome. Median follow-up duration was 7.7 years (range 2-25.2 years). Gender ratio, onset age, and follow-up duration were comparable between EU and LA patients. At study visit, EU patients had a greater frequency of active disease, as measured with MDAA (51.1\% vs. $35.2 \%)$ and DAS $(64.8 \%$ vs. $54 \%)$, whereas LA patients had a greater frequency of muscle weakness, as measured with the CMAS (62.9\% vs. $44.3 \%)$, and muscle damage, as measured with the MDI ( $41 \%$ vs. $30.1 \%)$.

\section{Results}

Table 1 shows the frequency of drugs administered to JDM patients in EU and LA centers.

\section{Conclusion}

Use of pulse iv steroids, CyA, AZA and CPM was more common in EU centers, whereas LA centers used more frequently MTX and AM. EU and LA centers administered iv Ig with equal frequency. 
Table I: Frequency of drugs administered to JDM patients in EU and LA centers

\begin{tabular}{|c|c|c|c|c|c|c|c|c|c|}
\hline & Oral/iv steroids & Pulse iv steroids & MTX & CyA & $\operatorname{lv} \lg$ & AM & AZA & Oral CPM & Pulse iv CPM \\
\hline$E U(N=246)$ & 97.6 & 50 & 50.8 & 35 & I7.I & 26 & 13.4 & 5.3 & 8.5 \\
\hline $\mathrm{LA}(\mathrm{N}=236)$ & 99.6 & 33.2 & 61.4 & 15.7 & 17.4 & 39 & 5.9 & 2.1 & 4.2 \\
\hline
\end{tabular}

MTX: methotrexate; CyA: cyclosporine A; AM: antimalarials; AZA: azathioprine; CPM: cyclophosphamide

Publish with Bio Med Central and every scientist can read your work free of charge

"BioMed Central will be the most significant development for disseminating the results of biomedical research in our lifetime. " Sir Paul Nurse, Cancer Research UK

Your research papers will be:

- available free of charge to the entire biomedical community

- peer reviewed and published immediately upon acceptance

- cited in PubMed and archived on PubMed Central

- yours - you keep the copyright 